\title{
How does occupational stress affect individuals employed in textiles? An exploratory study from Pakistan
}

DOI: 10.35530/IT.072.05.20204

\author{
AFTAB AHMAD \\ AMJAD HUSSAIN \\ AYYAZ AHMAD
}

\author{
LUBNA SHAHEEN \\ USAMA ABRAR \\ FARZAN AHMAD KHAN
}

\begin{abstract}
REZUMAT
How does occupational stress affect individuals employed in textiles? An exploratory study from Pakistan

Occupational stress among the employees has become a major concern for the organizations without exemption for the textile and clothing industry, a major manufacturing industry of the developing countries. In Pakistan, it contributes $8.5 \%$ to the GDP and is a source of employment for $30 \%$ of the workforce. This research aims at exploring the effects of job stress amongst the individuals employed in textiles. For the purpose, data was collected from 1212 textile industry employees. Deployment of exploratory factor analysis (EFA) on the information collected resulted four stress impact factors, namely psychological, behavioural, performance and effectiveness, and physical. The factors described an overall accumulative variance of $60.87 \%$, with psychological as the most significant, explaining $40 \%$ of the total. Results of this work disclose that how Occupational Stress affect the employees of textile and clothing industry. There is a need to understand the complexity of stress phenomenon so that the stress management intervention strategies could be designed and implemented accordingly. Findings of this research may be helpful in unfolding the complexity of stress phenomenon and these can be used as a guideline for the design and promotion of more acceptable and viable approaches or strategies for real-time benefits realization at individual and organizational level in terms of higher job satisfaction, motivation and productivity.
\end{abstract}

Keywords: behavioural, effects, employees, exploratory factor analysis, job stress, performance and effectiveness, physical, psychological, textile industry

\section{Cum influențează stresul profesional persoanele angajate în domeniul textil? Un studiu explorator din Pakistan}

Stresul profesional în rândul angajaților a devenit o preocupare majoră pentru organizațiile din industria textilă și de îmbrăcăminte, o industrie importantă în țările în curs de dezvoltare. În Pakistan, aceasta reprezintă 8,5\% din PIB și o sursă de ocupare a forței de muncă pentru $30 \%$ din populație. Această cercetare vizează analiza influenței stresului la locul de muncă în rândul persoanelor angajate în industria textilă. În acest scop, au fost colectate date de la 1212 angajați din industria textilă. Implementarea analizei factorilor exploratori (EFA) asupra informațiilor colectate a avut ca rezultat patru factori de impact asupra stresului, și anume cel psihologic, cel comportamental, cel de performanță și eficientă și cel fizic. Factorii au descris o varianță cumulativă globală de 60,87\%, factorul psihologic fiind cel mai semnificativ, cu 40\% din total. Rezultatele acestei lucrări dezvăluie modul în care stresul profesional afectează angajații din industria textilă și de îmbrăcăminte. Este necesar să se înțeleagă complexitatea fenomenului, astfel încât strategiile de intervenție în gestionarea stresului să poată fi proiectate și implementate în consecință. Rezultatele acestei cercetări pot fi utile pentru a dezvolta complexitatea fenomenului și acestea pot fi folosite ca ghid pentru proiectarea și promovarea unor abordări sau strategii acceptabile și viabile, pentru realizarea beneficiilor în timp real la nivel individual și organizational, în termeni de satisfacție profesională, motivație și productivitate.

Cuvinte-cheie: comportamental, efecte, angajați, analiza factorilor exploratori, stresul la locul de muncă, performanță și eficiență, fizic, psihologic, industria textilă

\section{INTRODUCTION}

There is no worldwide harmony upon the definition of stress. According to McEwen [1], "Stress is a word used to describe experiences that are challenging emotionally and physiologically". Opposing the vision of stress as a disturbing stimulus, other definitions give a sight into which organism are confronted and as to how stress is reacted by human being. Stress responses are constantly tracked by healing course of actions, which might be negotiated when stresses are dangerous, long-lasting, or unacquainted [2, 3]. For that reason, stressful occasions emerge to mount up from the beginning of life, and this collective hardship might have an intense effect on a broad spectrum of health upshots [4]. In the decade of 1980, occupational stress was recognized amongst the ten foremost occupational health issues in the United States and probable all through the Western developed countries. Thereupon, researchers started designing a prevention plan to deal with that was 
called a pandemic of stress [5]. It is a collectively agreed fact that effective use of HR is vital for the successful accomplishment of organizational objectives in terms of optimized work performance where human is the fundamental constituent of any system that controls executions throughout and ultimately responsible for achieving benefits in terms of repute of the organization, profit, productivity, quality etc. Organizational work performance is linked with stability of the human resource whose wellness is coupled with the effective occupational stress management [6]. Job-related stress is an international issue. In the year 2017-2018 in Great Britain, according to the HSE-2019 report cited by Ahmad et al., job-stress related infirmities were established as major reasons for $44 \%$ of the occupational ill-health cases which lost around $57 \%$ working days $[7,8]$. In a study on the textile industry employees, $70 \%$ reported in the range of moderate through severe stress levels [7] while $86 \%$ in another study which was carried only on the managers [9]. Addressing stress related issue of the employees of any organization is vital. This research aims at investigating the effects or impacts of jobrelated stress amongst the individuals employed in textiles at Pakistan.

The textile and clothing industry is considered as the biggest export-oriented manufacturing sector of Pakistan. The textile industry is believed to be very acute and central player in the country's economy. This sector gives $8.5 \%$ to the GDP and a source of employment to about $30 \%$ of 49 million workforce of the country. It adds up above $50 \%$ in the nation's entire out country sales. Within Asian countries, Pakistan is fourth largest cotton producer and the 8th leading exporter of textiles [10]. Like other sectors, competitiveness is considered as one of the main challenges being faced by the textile sector as well. In fact, effective and optimal use of the human resource is the fundamental variable that directly affects productivity and quality. In this respect, top management put high pressure on their employees which is likely to produce stress. Currently markets are becoming more competitive and globally wellconnected where work stress is becoming a more prominent among the employees and its management is becoming more challenging.

\section{LITERATURE REVIEW}

Occupational stress is accepted as a real well-being problem for individuals, companies, and the society at large. It is clear that WMSDs (work-related musculoskeletal disorders) are the outcomes of the interface of manifold stressors linked with the work itself, the work organization, the work environment and other personal factors [11, 12]. It impacts the human body unfavourably and negatively affects the organizational and individual performance [13, 14]. Reduction in efficacy, capacity to work as per plans, enthusiasm; dearth of creativity, lack of compassion for the organization, and augmented happening of "perceived contract breach" are also among the conse- quences of stress [15-18]. Job stress linked with disagreement and intense work-load is substantiated to be considerably and adversely related with almost entire aspects of job satisfaction (career opportunities, physical environment, job enrichment, management style, job security and rewards) [19]. Subsistence of negative inter-relationship has been observed inbetween workplace stress and the individuals' job performance [20]. As far as the well-being of the employees is concerned, job-stress is an established issue for the stakeholders. As stress affects all the organizational functions, hereafter proper deliberation is needed for its prevention and control [21].

Stress is a complex phenomenon so it is imperative to comprehend all of its acquaintances. The earlier stress-related reviews mainly speak about medical services, sports, teaching, and occupations in general [15, 22-24]. The stress-related literature pertaining to the textile industry is scarce, even the literature to play with does not wrap up the entire sector [25]. Moreover, as mentioned earlier that little emphasis has been given to explore stress phenomenon in industrial environments in detail especially textile sector organizations of developing countries like Pakistan where deployment of efficient research activities is indispensable [26]. Keeping in mind the complexity of the stress and its management, in this article, we have tried to address a very important question that how stress impacts the individuals as far as their psychological; behavioural; physical; and performance and effectiveness conditions are concerned. In this way, this research attempts to further unfold work stress phenomenon that can help in developing a better understanding of the process and how it is linked with different demographic variables so that more logical and effective intervention mechanisms could be designed and implemented.

\section{MATERIALS AND METHODS}

In order to explore the occupational-stress effect factors among the employees of textile and clothing industry a self-designed research instrument was used to obtain the opinions of the subjects of the study. Thereafter, the data collected was analysed.

\section{Study subjects}

Overall, 1212 personnel were at random chosen for the data collection. The personnel positioned at all levels, in the four major sub-sectors of the textile and clothing industry, explicitly: fibre and fabric manufacturing (spinning and weaving); socks manufacturing; apparel manufacturing and home textiles, were chosen to take part in the poll. Data was collected from 23 diverse organizations. Employees of these organizations, irrespective of their gender were qualified to be the subjects of the study. For the purpose of collecting an overall perspective of the employees of textile organizations, personnel working at all levels of the organizations were selected for this study. All of them were from divergent branches of the companies under study. 


\section{Opinion poll}

So as to reach the desired objectives of this crosssectional study, data was gathered by making the use of a survey which was the collection of variables relating to the impacts of workplace stress. Prior to commencing the poll, well-prepared staff educated all the subjects about the intention behind the activity, structure of the poll and how to record their responses. While filling the survey, the trained research staff remained reachable to answer back the questions of participants. Also, every review was instantly ensured for missing information and the subjects were insisted for the same. Respondents were informed as the surveys are anonymous and no specific information will be shared with anyone at any stage of the research and the information will be used only for research purpose.

\section{Instrument}

A self-designed Instrument was used to attain the study objective. It is the part of the instrument designed for a big research project, though its development is not the purview of this study, and has been used by authors [27]. It was composed of 22 items framed to explore the effects of workplace stress on the individuals belonging to manufacturing sector organizations. The opinions of the respondents were taken on a 5-point Likert type scale ranging between 1 (signifying no impact) and 5 (signifying high impact): 5 = Always, 4 = Often, 3 = Sometimes, $2=$ Seldom, $1=$ Never. The respondents were required to opt for any number of the scale as a response and the responses were then summed to calculate the impact score; where higher scores indicated higher impact and vice versa. Assertions were typically like: I suffer from frequent depression. The instrument was instituted as the most consistent as had the Cronbach's alpha value 0.924 .

\section{Statistical procedures}

Descriptive analyses besides Exploratory Factor Analysis (EFA) utilizing Principal Component Analysis as the Extraction Method and Oblimin with Kaiser Normalization as the Rotation Method were used to ascertain the effects of stress. EFA has been widely used by the researchers in exploring a set of latent constructs underlying a series of calculated variables, for example, Bayraktar et al. used in case of employee involvement and rewarding [28-32]. Before doing this, validation of the appropriateness of EFA as an exploratory tool was determined by employing Bartlett's test of sphericity in addition to the KMO (KaiserMeyer-Olkin) measure of sampling adequacy. After identification of the factors, their reliability was determined by means of computing the Cronbach alpha coefficient [33]. Furthermore, two descriptive statistics, arithmetic means, and standard deviations were calculated for each factor. The response score of individual items for each point of the Likert scale was aggregated to determine a summary score. SPSS version 23.0, for Windows, was employed to generate the results of the study.

\section{RESULTS AND DISCUSSION}

\section{Exploratory Factor Analysis}

Prior to deploying EFA, sample adequacy for the factor analysis of the information gathered for identification of the effects of occupational stress was assessed through the KMO measure of sample adequacy and Bartlett's test of sphericity. Bartlett's test of sphericity provided a value of zero that is acceptable as it's less than 0.05 while the KMO test shows value 0.946 which is also acceptable (table 1). The quality of the correlation among the variables has been concluded strong and hence data is appropriate for multivariate investigations such as factor analysis.

\begin{tabular}{|c|c|c|}
\hline \multicolumn{3}{|c|}{ KMO AND BARTLETT'S TEST } \\
\hline \multicolumn{2}{|c|}{ Indicator } & Value \\
\hline \multicolumn{2}{|c|}{$\begin{array}{l}\text { Kaiser-Meyer-Olkin Measure of Sampling } \\
\text { Adequacy }\end{array}$} & 0.946 \\
\hline \multirow{3}{*}{$\begin{array}{l}\text { Bartlett's Test } \\
\text { of Sphericity }\end{array}$} & Approx. Chi-Square & 11296.647 \\
\hline & $\mathrm{df}$ & 231 \\
\hline & Sig. & 0.000 \\
\hline
\end{tabular}

After employing Principal Component Analysis as an extraction method; rotating the component matrix by employing Oblimin with Kaiser Normalization and utilizing the factors' retention principle based on the Eigen value where the factors having value greater than 1 are to be retained, four factors were identified (table 2). Scree plot criterion recommended for retention of the factors also confirmed 4 factors (figure 1).

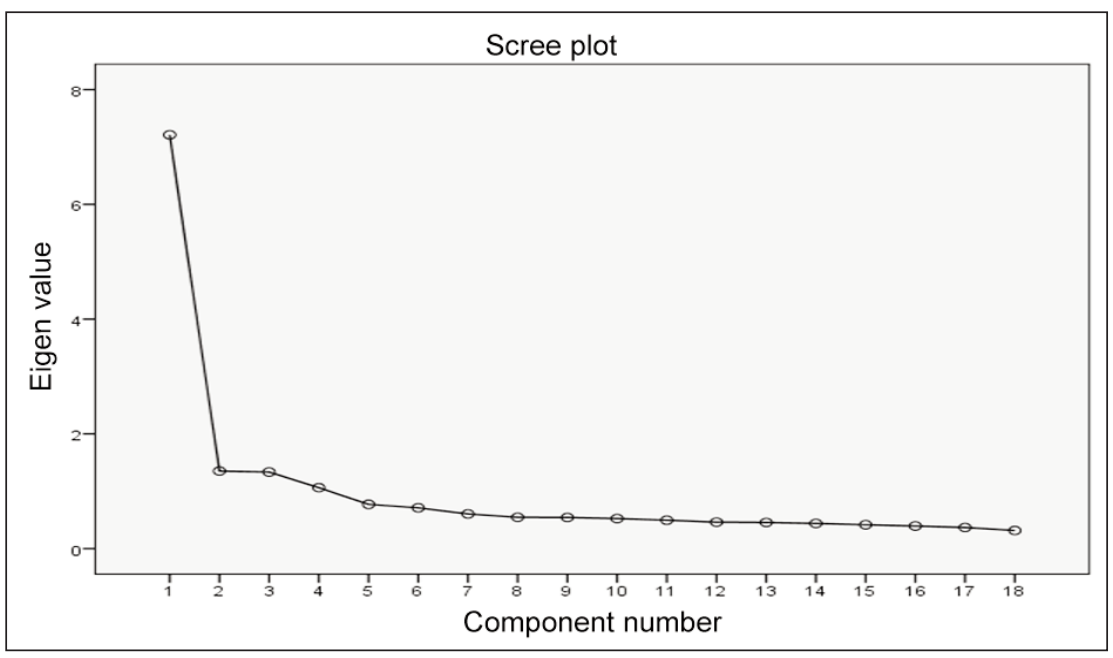

Fig. 1. Scree Plot $(\mathrm{N}=1212)$ 


\begin{tabular}{|c|c|c|c|}
\hline \multicolumn{4}{|c|}{ EXPLORATORY FACTOR ANALYSIS } \\
\hline & $\begin{array}{l}\text { Item description (Eigen values; variance proportion; } \\
\text { Cronbach's alpha; mean } \pm \text { SD) }\end{array}$ & Factor loading & Mean (SD) \\
\hline \multicolumn{4}{|c|}{ Factor 1: Psychological $(7.21 ; 40.08 \% ; 0.87 ; 1.88 \pm 0.74)$} \\
\hline 1 & I suffer from frequent depression & 0.811 & $1.8(1.0)$ \\
\hline 2 & I often suffer from sleeplessness & 0.806 & $2.0(1.0)$ \\
\hline 3 & I used to avoid people & 0.803 & $1.9(0.9)$ \\
\hline 4 & I often suffer from anger/ hostility & 0.706 & $1.9(1.0)$ \\
\hline 5 & I have had dizzy spells & 0.697 & $1.7(0.9)$ \\
\hline 6 & I experience worsening relations with colleagues, family and friends & 0.654 & $1.9(1.0)$ \\
\hline 7 & I often suffer from anxiety & 0.591 & $2.0(1.0)$ \\
\hline \multicolumn{4}{|c|}{ Factor 2: Performance and Effectiveness $(1.35 ; 7.52 \% ; 0.79 ; 2.15 \pm / 0.81)$} \\
\hline 1 & My judgment is clouded or not as good as it was & 0.846 & $2.2(1.0)$ \\
\hline 2 & I am ineffective in resolving family issues & 0.775 & $2.0(1.0)$ \\
\hline 3 & Often, I am unable to complete the task as per schedule & 0.762 & $2.2(1.0)$ \\
\hline 4 & Usually, I am unable to do all the things in a day that I must do & 0.678 & $2.2(1.1)$ \\
\hline \multicolumn{4}{|c|}{ Factor 3: Behavioural $(1.33 ; 7.35 \% ; 0.75 ; 2.26 \pm / \pm 0.87)$} \\
\hline 1 & I have become short tempered & 0.862 & $2.4(1.1)$ \\
\hline 2 & I become very frustrated at having to wait in a queue & 0.835 & $2.3(1.1)$ \\
\hline 3 & I experience mood swings & 0.491 & $2.1(1.0)$ \\
\hline \multicolumn{4}{|c|}{ Factor 4: Physical Effects (1.06; 5.92\%; 0.77; $2.15 \pm / 0.76)$} \\
\hline 1 & I have headaches & -0.806 & $2.1(0.9)$ \\
\hline 2 & I have felt tired & -0.802 & $2.4(1.0)$ \\
\hline 3 & $\begin{array}{l}\text { I get tension or muscle spasms/pains in my face, jaw, neck, chest, head, } \\
\text { lower back or shoulders }\end{array}$ & -0.724 & $2.0(1.0)$ \\
\hline 4 & I lack physical energy & -0.629 & $2.0(1.0)$ \\
\hline
\end{tabular}

The items which did not load onto a specific factor with an item loading of 0.30 or greater were not taken. Altogether, there were 18 items which meet the criteria. These four factors explain variation of $60.87 \%$ which is more than the requisite value of $60 \%$ variance. In the subsequent paragraphs, further details of the factors selected have been described. Factor 1: Seven items laden on the factor where all speaks about the psychological impact thus the factor is termed as Psychological. All the items loaded well on the factor while three loaded heavily, above 0.80. It is an important factor as more than half of the entire variance $(40.088 \%)$ is explained by this only component or factor. Nevertheless, mean of the component on the 5-point Likert type scale is 1.88 with standard deviation 0.74 (table 2).

Factor 2: Four variables subsist into the factor and all of them have significant loading. Since all the variables attributes to the impact of work-stress on the performance and effectiveness of the personnel, so the factor is termed as Performance and Effectiveness. As shown in table 2, factor mean is 2.15 with a standard deviation 0.81 .

Factor 3: The factor 3 is emerged by the variance derivation of three variables on the factor having factor mean as 2.26 with standard deviation 0.87 . All the variables speak about the behavioural effects of stress so termed as Behavioural (table 2).

Factor 4: Four variables describe factor 4 and each is heavily loaded (table 2). As each relates to the physical impact on the individuals and hence the factor is titled as Physical. The factor mean is 2.15 with standard deviation 0.76 (table 2).

\section{Reliability}

Table 2 also shows statistics for the Cronbach alpha coefficient of every factor. Factor 1 has the highest reliability coefficient value $(0.873)$ and all the remaining factors have values greater than 0.70 representing good reliability levels and distinctive evenness [33]. The reliability coefficients are in agreement with other studies available in the literature [34].

\section{Correlations among the components}

The component correlation matrix shown in table 3 depicts that inter correlation among the factors emerged from deployment of EFA. It is obvious that the correlations are beyond 0.5 except two which are slightly above 0.5 . It depicts that each component explores distinctive aspects.

Previous stress related literature mainly pertains to other sectors and is rare on textile industry. Even the available does not cover the sector as whole [25]. In 
the areas other than textile, for example, fatigue, loss of focus, occupational lake of interest, obstruction of alertness, and monotony were found as effects of stress in radiographers at Ghana, [35]. A study on the shift workers found adverse effects on employees' mental health and mood states [36]. Rapid turn down in global cognition came out as the effect of severe stress among older African Americans [37]. Evidently, numerous studies, in the past, were conducted to on stress. Though, very little work is found about the potential effects of stress at work and particularly in textiles. The present study focuses on a single sector where attempt has been made to find out the stress impact factors in textile industry by capturing a broader perspective by covering almost all types of textile organizations, explicitly fiber and fabric manufacturer, socks manufacturer, apparel manufacturer, and home textiles.

Table 3

\begin{tabular}{|l|c|c|c|c|}
\hline \multicolumn{5}{|c|}{ CORRELATION MATRIX } \\
\hline \multicolumn{1}{|c|}{ Factors } & $\mathbf{1}$ & $\mathbf{2}$ & $\mathbf{3}$ & $\mathbf{4}$ \\
\hline Psychological & 1.000 & & & \\
\hline $\begin{array}{l}\text { Performance and } \\
\text { effectiveness }\end{array}$ & 0.533 & 1.000 & & \\
\hline Behavioural & 0.413 & 0.325 & 1.000 & \\
\hline Physical effects & -0.516 & -0.476 & -0.394 & 1.000 \\
\hline
\end{tabular}

\section{CONCLUSIONS}

This research aims at capturing an insight of job stress phenomenon in terms of its effects. Deployment of EFA for finding effects of job stress concluded four factors: Psychological, Performance and Effectiveness, Behavioural and Physical as key effect areas. Factors described a $60.87 \%$ total variance where Psychological factor happened to be the most significant factor in terms of variance explained. However, more employees have reported having behavioural impact followed by physical; and performance and effectiveness impacts. Health outcomes, namely anxiety, depression were identified as the effects of stress in RMG at Bangladesh [25]. Both the symptoms relate to the Psychological factor, the most significant factor explored in the current examination. The situation is much worrying and needs intercessions. This article contributes a comprehensive and prioritized list of factors pertaining to the effects of job stress among the individuals employed in textiles. Findings of this work further highlight that work stress is a multifarious phenomenon which is subjective to number of internal as well as external factors; so before devising some control or prevention strategies, it should be investigated appropriately at some earlier stage so that effectiveness of the interventions might be enhanced. Findings of this work can be used by the stakeholders in devising interventions which, apart from controlling the phenomenon, may lessen its effects on the individuals. For instance, here Psychological has been emerged as the most significant effect so the strategies can target this particular factor. In short, the strategies can be 'findings specific'. Future work might be done on finding the relationship between different causes of job stress and how a particular cause is linked with a specific effect. This will help in developing and applying stress controlling strategies in a more logical and realistic way so that their effectiveness might be increased. Such kind of studies can further help in understanding the phenomenon that can ultimately leads towards the development of more realistic intervention models. In this way, challenges like human variability, diversity and socio-technical complexities of modern working systems can be addressed in a better way.

\section{ACKNOWLEDGMENTS}

Assistance of the organizations in information gathering is highly accredited.

\section{REFERENCES}

[1] McEwen, B., Physiology and neurobiology of stress and adaptation: central role of the brain, In: Physiological Reviews, 2007, 87, 3, 873-904

[2] Koolhaas, J., Bartolomucci, A., Buwalda, B., et al., Stress revisited: a critical evaluation of the stress concept, In: Neuroscience and Biobehavioral Reviews, 2011, 35, 5, 1291-1301

[3] Stults-Kolehmainen, M., Bartholomew, J., Psychological stress impairs short-term muscular recovery from resistance exercise, In: Medicine and Science in Sports and Exercise, 2012, 44, 11, 2220-2227

[4] Miller, G., Chen, E., Cole, S., Health psychology: developing biologically plausible models linking the social world and physical health, In: Annual Review of Psychology, 2009, 60, 501-524

[5] Sauter, S., Murphy, L., Hurrell, J., Prevention of work-related psychological disorders: A national strategy proposed by the National Institute for Occupational Safety and Health (NIOSH), In: American Psychologist, 1990, 45, 1146-1158, http://doi.org/10.1037/0003-066X.45.10.1146

[6] Quick, J., Henderson, D., Occupational Stress: Preventing Suffering, Enhancing Wellbeing, In: International Journal of Environmental Research and Public Health, 2016, 13, 5, 459, http://doi.org/10.3390\%2Fijerph13050459

[7] Ahamd, A., et al., Perceived stress: role and levels of demographics - a cross-sectional study of textile industry employees, In: Industria Textila, 2020, 71, 2, 180-185, http://doi.org/10.35530/IT.071.02.1643

[8] Ahmad, A., et al., Do Demographic Factors Affect Work-stress? A Case Study of Textile and Clothing Industry in Pakistan, In: Pakistan Journal of Agriculture Sciences, 2021, 58, 1, 307-313, https://doi.org/10.21162/PAKJAS/21.597

[9] Ahmad, A., et al., Workplace Stress Assessment among Managers of Textile Industries at Developing Countries: A Case Study from Pakistan, In: Advances in Human Factors, Business Management and Leadership, AHFE 2017, Springer, Cham, 2018, 594, 382-391

[10] Simion, C.-P., et al., Economic and IT determinants of innovative projects in the textiles, wearing apparel, leather and related products industry, In: Industria Textila, 2018, 69, 4, 338-344, http://doi.org/10.35530/IT.069.04.1478 
[11] Ahmad, A. et al., Investigation of Ergonomic Working Conditions of Sewing and Cutting Machine Operators of Garment Manufacturing Industry, In: Industria Textila, 2021, 72, 3, 309-314, http://doi.org/10.35530/IT.072.03.1723

[12] Sharma, R., Singh, R., Work-related musculoskeletal disorders, job stressors and gender responses in foundry industry, In: International Journal of Occupational Safety and Ergonomics, 2014, 20, 2, 363-373

[13] Tucker, M., Jimmieson, L., Nerina L., Oei, T.P., The relevance of shared experiences: A multi-level study of collective efficacy as a moderator of job control in the stressor-strain relationship, In: Work \& Stress: An International Journal of Work, Health and Organizations, 2013, 27, 1, 1-21

[14] Senaratne, S., Rasagopalasingam, V., The causes and effects of work stress in construction project managers: the case in Sri Lanka, In: International Journal of Construction Management, 2017, 17, 1, 65-75

[15] Adriaenssens, J., Veronique, D., Maes, S., Causes and consequences of occupational stress in emergency nurses, a longitudinal study, In: Journal of Nursing Management, 2015, 23, 3, 346-382

[16] Bridger, R., Day, A., Mortan, K., Occupational stress and employees turnover, In: Ergonomics, 2013, 56, 11, 1629-1639

[17] Choi, S., Lee, J., Park, H., The effects of Psychological problems in employees' stress, self-esteem, and organizational commitment: the case of South Korean workplaces, In: Journal of Workplace Behavioural Health, 2015, 30, 1, 2, 179-190

[18] Xavier, I., Jepsen, D., The Impact of Specific Job Stressors on Psychological Contract Breach and Violation, In: Human Factors and Ergonomics in Manufacturing \& Service Industries, 2015, 25, 5, 534-547

[19] Trivellas, P., Panagiotis, R., Charalambos Platis, C., The effect of job related stress on employees' satisfaction: A survey in Health Care, In: Procedia - Social and Behavioral Sciences, Budapest , 2013, 73, 718, 2013, 718-726

[20] Kakkos, N., Trivellas, P., Investigating the link between motivation, work stress and job performance. Evidence from the banking industry. In: $8^{\text {th }}$ International Conference on Enterprise Systems, Accounting and Logestic ( $8^{\text {th }}$ ICESAL, '11), 2017, Thassos, 408-428

[21] Brown, Z., Uehara, D., Coping with teacher stress: A research synthesis for Pacific Resources for Education and learning, 2009, Available at: http://www.prel.org/products/ [Accessed on January 2020]

[22] Kizhakkeveettil, A., et al., Perceived stress and fatigue among students in a doctor of chiropractic training program, In: Journal of Chiropractic Education, 2017, 31, 8-13

[23] Pettit, M., DeBarr, K., Perceived Stress, Energy Drink Consumption, and Academic Performance Among College Students, In: Journal of American College Health, 2011, 59, 335-341

[24] Baka, Ł., Bazińska, R., Polish adaptation of three self-report measures of job stressors: the Interpersonal Conflict at Work Scale, the Quantitative Workload Inventory and the Organizational Constraints Scale, In: International Journal of Occupational Safety and Ergonomics, 2016, 22, 1, 32-39

[25] Steinisch, M., et al., Work stress: Its components and its association with self-reported health outcomes in a garment factory in Bangladesh - Findings from a cross-sectional study, In: Health \& Place, 2013, 24, 123-130

[26] Kanat, S., et al., SWOT analysis of Pakistan's textile and clothing industry, In: Industria Textila, 2018, 69, 502-510, http://doi.org/10.35530/IT.069.06.1488

[27] Ahmad, A., et al., Effects of Workplace Stress on Managers of Textile Industries of Developing Countries: A Case Study from Pakistan, In: Advances in Human Factors, Business Management and Society, AHFE 2018, Advances in Intelligent Systems and Computing, Springer, Cham, 2019, 783, 500-507

[28] Ahmad, A., Hussain, A., Ahmad, Q.W., Islam, B.U., Causes of Workplace Stress in Textile Industry of Developing Countries: A Case Study from Pakistan, In: Goossens R. (eds) Advances in Social \& Occupational Ergonomics. Advances in Intelligent Systems and Computing, Springer, Cham, 2017, 487, 283-294

[29] Ahmad, A. et al., Impacts of Workplace Stress: An Exploratory Cross-Sectional Study of Oil and Gas Sector in Pakistan, In: Sukkur IBA Journal of Management and Business, 2021, 8, 1, 70-79

[30] Ahmad, A., et al., Quantifying the Consequences of Perceived Stress in the Textile \& Clothing Sector through Structural Equation Modeling, In: Mathematical Problems in Engineering, 2021, 2021, 5597111, https://doi.org/10.1155/ 2021/5597111

[31] Bayraktar, C., Araci, O., Karacay, G, Calisir, F., The mediating effect of rewarding on the relationship between employee involvement and job satisfaction, In: Human Factors and Ergonomics in Manufacturing and Service Industries, 2017, 27, 45-52

[32] Ahmad, A., Hussain, A., Mughal, M., Mufti, N., Saleem, M., Path Analysis of the Antecedents and Occupational Stress Among the Managers of the Textile Industries: A Cross-Sectional Study from Pakistan Using PLS-SEM, In: Advances in Social and Occupational Ergonomics, Proceedings of the AHFE 2019 International Conference on Social and Occupational Ergonomics, Goossens R.H.M. and Murata A. ed., Springer, Cham, 2020, 480-490

[33] Field, A., Discovering Statistics Using SPSS, 2nd ed., Sage Publications, London, 2005

[34] Jackson, L., Rothmann, S., An Adapted Model of Burnout for Teachers in South Africa, In: South African Journal of Education, 2005, 25, 2, 100-108

[35] Ashong, G.G.N.A., et al., Effects of occupational stress and coping mechanisms adopted by radiographers in Ghana, In: Radiography, 2015, 22, 2, 112-117, http://dx.doi.org/10.1016/j.radi.2015.09.002

[36] Srivastava, U., Shift Work Related to Stress, Health and Mood States: A Study of Dairy Workers, In: Journal of Health Management, 2010, 12, 2, 173-200

[37] Turner, A., James, B., Capuano, A., Aggarwal, N., Perceived stress and cognitive decline in different cognitive domains in a cohort of older African Americans, In: The American Journal of Geriatric Psychiatry, 2016, 25, 1, http://doi.org/10.1016/ j.jagp.2016.10.003

\section{Authors: \\ AFTAB AHMAD ${ }^{1,2}$, AMJAD HUSSAIN ${ }^{3}$, AYYAZ AHMAD $^{4}$, LUBNA SHAHEEN ${ }^{5}$, USAMA ABRAR ${ }^{2}$, FARZAN AHMAD KHAN ${ }^{6}$}

${ }^{1}$ University of Engineering and Technology, Department of Industrial and Manufacturing Engineering, 54890, Lahore, Pakistan

${ }^{2}$ NFC Institute of Engineering and Fertilizer Research, Department of Electrical Engineering, 38090, Faisalabad, Pakistan

${ }^{3}$ University of Engineering and Technology, Department of Mechanical Engineering, 54890, Lahore, Pakistan

${ }^{4}$ University of the Punjab, Department of Industrial Engineering and Management,

Quaid-e-Azam Campus, 54590, Lahore, Pakistan

5 University of Malaya, Faculty of Education, Department of Educational Psychology, 50603 Kuala Lumpur, Malaysia

${ }^{6}$ New York University, Office of Global Education, Abu Dhabi, 129188, Saadiyat Island, Abu Dhabi, United Arab Emirates

\section{Corresponding author:}

AFTAB AHMAD

e-mail: aftabahmadrao@gmail.com 